$$
\frac{h}{m_{n} c}+\frac{\delta_{1} h}{m_{\pi} c}+\frac{\delta_{2} h}{m_{n} c}+\frac{\delta_{8} h}{m_{\mu} c}=0 .
$$

It can easily be verified that the only solution of this equation compatible with the condition $\varepsilon \equiv \frac{m_{\pi}}{m_{\mu}}>1$, is

$$
\varepsilon=1+2 \frac{m_{\pi}}{m_{n}}
$$

If this is combined with (5), one obtains

$\varepsilon=1+\frac{1}{\pi}=1 \cdot 32$ (observed value, $1 \cdot 33 \pm 0 \cdot 05$ ),

a relation which was first derived by me from a less general consideration ${ }^{4}$.

From (6) and (9) follows the value for the electronic mass number of the $\mu$-meson :

$\frac{m_{\mu}}{m_{e}}=\frac{292}{1 \cdot 32}=221$ (observed value, $216 \pm 5$ ).

Consider finally the process of annihilation of a proton and an antiproton. The annihilation of an electron and a positron results in the formation of two equal photons. I suggest that the annihilation of a proton and an antiproton, as this involves electromagnetic and nuclear interaction fields, results in the creation of a pair of photons and a pair of neutral mesons ('neutrettos') or charged mesons.

In the first case, we may replace the process by two identical processes of transmutation of a neutron into a photon and a neutretto of mass $m_{\tau}$. For this, proposition $(\mathrm{V})$ provides the equation

$$
\frac{h}{m_{n} c}+\frac{\delta_{1} c}{v}+\frac{\varepsilon_{2} h}{m_{\tau} c}=0,
$$

to which has to be added the energy relation

$$
m_{n} c^{2}=h v+m_{\tau} c^{2} \text {. }
$$

It can atgain easily be shown that the only possible values for the energy ratio $\eta \equiv \frac{m_{\tau} c^{2}}{h \nu}$ of neutretto and photon, resulting from this equation, are $\eta=\frac{1+\sqrt{5}}{2}=1.618$ and $\eta^{\prime}=\frac{\sqrt{5}-1}{2}=\eta-1=\frac{1}{\eta}$.

Thus the two types of created particles have the fixed energy ratio $\eta_{i}$.

From (12) and (13) one obtains two possible values for the mass ratio $m_{n} / m_{r}$, namelv,

$$
1+\eta=2.618 \text { and } 1+\eta^{\prime}=\eta=1.618 \text {, }
$$

from which by means of (4) the electronic mass numbers of the two possible neutrettos are calculated :

$$
m_{\tau} / m_{\boldsymbol{e}}=701 \text { or } m_{\tau} / m_{\boldsymbol{B}}=1,135 \text {. }
$$

I venture to suggest that such a neutretto can in turn produce a pair of $\tau$-mesons by interaction with a nucleon, in analogy to the process of 'pair-production' by $a_{0}$ photon, and that this is the process first described by Rochester and Butler and more recently by Anderson and collaborators ${ }^{10}$ in what they call "decay of the first kind".

If, on the other hand, the annihilation process of proton and antiproton results in the creation of a pair of charged mesons, it cannot be split up into two symmetrical halves as considered above, and hence the present theory is not capable of predicting the masses of these mesons. It seems not unreasonable, however, to assume that these mesons may have a continuous mass spectrum within the limits of (14). They could therefore be identical with the so-called $\tau$-mesons which have been described by various observers ${ }^{11}$; indeed, the most recent determination of the masses of these particles by Butler, Rosser and Barker ${ }^{12}$ gives the limits 650-1,140 $m_{e}$.

The process of the transmutation of a $\tau$-meson into a lighter particle, first observed by Rochester and Butler ${ }^{8}$ and more recently by Anderson and collaborators ${ }^{10}$, in their "decay of the second kind" process, may well be analogous to the transmutation of a $\pi$-meson into a $\mu$-meson. The mass $m_{\tau}{ }^{\prime}$ of the secondary particle would then, according to $(8)$, be given by

$$
\frac{m_{\tau}}{m_{\tau}^{\prime}}=1+2 \frac{m_{\tau}}{m_{n}} \sim 2 .
$$

As I have already emphasized elsewhere ${ }^{5}$, it is indeed in keeping with the principles of the present theory to ascribe a continuous mass spectrum to mesons in analogy to the continuous frequency spectrum of photons. The appearance of mesons with specific rest masses must be regarded as the outcome of specific nuclear processes, just as the appearance of specific spectral lines is the outcome of specific electronic processes in the atomic shells.

1 Flint, H. T., Nature, 166, 30 (1950).

[Aug. 7.

${ }^{2}$ Fürth, R., Z. Phys., 57, 429 (1929).

${ }^{3}$ For example, Freeman, I. M., Nature, 165, 933 (1950). Stephenson, G., Nature, 185, 1018 (1950).

4 Fürth, R., Nature, 162, 772 (1948).

${ }^{5}$ Fürth, R., Research (Colston Papers on Cosmic Radiation), 149 (1949). - Born, M., Proc. Roy. Soc., A, 165, 291 (1938): for list of references
to other papers, see Nature, 165, 269 (1950).

'Fürth, R., Z. Phys., 85, 294 (1933).

s For list of references, see Broda, E., Feather, N., and Wilkinson D. H.. International Conference on Fundamental Particles, 114

- Rochester, G. D., and Butler, C. C., Nature, 160, 855 (1947).

10 Anderson, C., et al., Phys. Rev., 78, 290 (1950).

"For references, see, for example, Nature, 168, 16 (1950).

${ }^{22}$ Butler, C. C., Rosser, W. G. V., and Barker, K. H., Proc. Phys. Soc.. A, 63, $145(1950)$.

\section{MARINE BIOLOGY RESEARCH IN GREAT BRITAIN}

$\mathrm{N}^{\mathrm{T}}$ INETEEN papers on the physical and chemical properties of sea-water, movement of water on the ocean bed, and the life-history and habits of the animals living in the sea, make up a well-balanced group in the December issue of the Journal, issued by the Marine Biological Association of the United Kingdom.

A second paper by Mr. G. A. Steven on the biology of the mackerel (Scomber scombrus) is based largely on observations and plankton samples collected by fishermen engaged in the Newlyn deep-sea mackerel fishery, sole relic of the three West-Country fisheries, for the inshore Newlyn and Plymouth fisheries are no longer remunerative. P. G. Corbin (1947) mapped the spawning areas in the Celtic Sea, north-west and south-west of the Cornish peninsula, and Steven found that the most productive fishing areas lie on the fringes of those areas nearest to the land, from about one hundred miles west of the Scillies in March, and moving shorewards as the fish rise from the sea bed and migrate to shallower waters for active feeding. The post-spawning anadromous migration is correlated with the 'yellow water' recognized by 
the fishermen, and this proved on investigation to be water rich in zooplankton, particularly copepods.

Mr. Corbin contributes his tenth paper on the seasonal abundance of young fish, for the year 1948 . A continuation of the decline in the population of young fish, coupled with that of the planktonic organisms on which they feed, is in great contrast to the rich hauls of the year 1930, and the fortnightly averages of some species are now so low that they cannot be graphed against similar averages for the period 1930-34. Clupeids provide the highest figures, particularly in March and October. None was recorded in November, the only month in which they were absent. The haul of pilchard eggs in June was barely one-third that of a good year. Plankton other than young fish were also scarce. Calanus, Sagitta setosa and Muggicea atlantica show very low records.

The link between the larval stage and the adult form, so ably worked out in many species by Dr. Marie Lebour, is the subject of three papers in the present issue. One, by Dr. Lebour herself, deals with the lest larva and post-larva of Typton spongicola. This peculiar deep-orange larva was taken off the Eddystone, and changed in the laboratory to the post-larva, with loss of its double flexion but retention of the humped abdomen. The antennal scale and the exopodite of thoracic appendages 4-7 show a progressive decline from larva to adult. Nothing is known of the transition from the free post-larva to the sedentary adult living within a sponge. A similar post-larva was found in Bermuda in 1940 by Dr. Hilary Moore.

Mr. R. H. Millar describes the larval stage of Didemnum maculosum, a compound ascidian forming mouldy-looking incrustations on Laminaria roots in the littoral zone. The larva possesses four rows of stigmata and other pharyngeal characteristics of the adult zooid of the family Didemnidæ, but has only two anterior adhesive organs as in Trididemnum alleni.

Our knowledge of the life-history and local distribution of Arenicola marina has expanded considerably during the past fow years, owing to the careful and intensive studies of G. P. Wells, G. E. Newell and $G$. Chapman. In the present number the last two authors have worked out that the population density of lugworms in inter-tidal zones with high organic content depends upon particle size and depth of the 'top-soil'. Worms do, however, migrate from less to more favourable areas, especially in spring. In this way they came to inhabit a large mine crater on the Whitstable flats which had afterwards filled up with soft sandy mud in a bowl of clay. Dr. Newell was the first to discover the spawning and the early larval stages of Arenicola marina in Great Britain, and he now follows up the life-history by a study of the development between the larva with three chrtigerous segments and a post-larva, about $3 \mathrm{~mm}$. long, with twenty chrtigerous segments and six eyes, but no branchiæ. These post-larval stages are bottom dwellers enclosed in mucous tubes on pebble and Fucus zones, the habitat bearing out Newell's earlier suggestion that the lugworm has no pelagic stage in its life-history.

As a foretaste of the eagerly awaited Ray Society monograph on the Mysidacea by the late Prof.-W. M. Tattersall, which Mrs. Tattersall has prepared for the press, she gives a key for the mysids of the Plymouth area, which will prove useful to those of us who supplement daytime plankton hauls with coarse-net hauls at night.

The invasion of British shores by Mediterranean species occasionally occurs, and Miss U. M. Grigg describes the recent appearance of two large southern species of sea hares, Aplysia depilans and A. limacina, the former from Babbacombe and the latter from the Salcombe estuary. This is the third record from various points on the south coast of $A$. depilans, but the first of A. limacina. Dr. D. P. Wilson contributes beautiful photographs of the living animals.

Mr. G. M. Spooner investigated the absorption of strontium and yttrium by algæ, and found that radioactive strontium was taken up by brown seaweeds, Fucus serratus containing forty times as much as in sea-water, and about three times as much as Laminaria digitata. Red and green algæ absorb a negligible amount, Rhodymenia and Ulva containing less than in the sea. Radioactive yttrium is in inverse proportions, being least in the brown weeds. It is suggested that there is both ionic exchange and adsorption on surfaces, but in brown algæ primarily jonio exchange. Nitzschia takes up yttrium very heavily, probably by adsorption on the surface.

A preliminary article on volume measurement of water filtered by a plankton pump is contributed by Mr. H. Barnes, who uses an ex-National Fire Service pump, tests it by filling a tank and estimates the pumping-rate; filtering off the plankton would probably increase the accuracy. He suggests that the variability of net hauls is not entirely due to variation in the volume of water filtered, but this requires further investigation.

Dr. A. A. Aleem describes on ingenious apparatus for producing artificial tides in an inverted bell-jar by $\varepsilon_{0}$ drip-siphon method, which can be adjusted to give two high and two low tides within twenty-four hours. In a second paper he details a method for estimating quantitatively the periodicity of epiphytic marine diatoms by computing the amount of diatom silica, after washing free from sand. The method can be adapted for planktonic diatoms, provided that the sample does not contain other organisms having a siliceous envelope.

Dr. W. A. P. Black and Dr. E. T. Dewar have worked on the correlation between some of the physical and chemical properties of the sea and the chemical constitution of the algæ. The samples of sea-water from three localities on the Argyllshire coast do not differ materially from those elsewhere as regards estimations of $p \mathrm{H}$, dissolved oxygen, nitrate and phosphate, in the different months of the year, August having the lowest record, though it has the highest temperature. Using species of Laminaria for the estimation of their chemical constituents, they found that a correlation does exist and that rapid photosynthesis occurs from March to early July, when nitrate and phosphate are plentiful, and are at their lowest in late July and August, but rise again in the autumn after vertical mixing and regeneration of the nutrients.

There are two papers on measurements of extinction coefficients. A quick method, taking only five minutes, for the determination of visibility depth in water, using selenium rectifier cells and colour filters, is described by Dr. W. R. G. Atkins, Dr. H. H. Poole and Mr. F. J. Warren, while Mr. M. H. W. Gall gives an account of his cruise in the North Sea and English Channel, during which extinction coefficients were determined at twenty-five stations, compared with 
Secchi disk readings, and correlated with selinity and temperature.

Finally, an interesting paper on water movements, entitled "Cascading over the Continental Slope", by Dr. L. H. N. Cooper and Mr. D. Vaux, deals with the cooling and sinking of the surface water in some winters over the Celtic Sea to a depth of about a hundred fathoms. This heavy water, coming into contact with the sea bed of the continental shelf, moves down it and flows along the bottom to the greater depths beyond. Mr. G. A. Steven has suggested the term cascading for this movement, which the authors believe occurs in limited areas only. Cascading will convey not only oxygen and nutrients to the depths, but also phyto- and zoo-plankton, which may in turn affect the fish population. Local cascading over flat-topped banks on the continental shelf during autumn cooling may favour the concentration of fish over declivities. Compensation is brought about by inflow from the Atlantic surfacewater, the North Sea and the Straits of Dover contributing little or none.

A supplementary list of insects and arachnids from the Plymouth shore areas has been added by Mr. R. E. Hall and Mr. H. C. Fountain.

N. B. EALES

\section{FIFTH INTERNATIONAL CONGRESS FOR MICROBIOLOGY}

$\mathrm{T}$ HE fifth International Congress for Microbiology was held at Rio de Janeiro during August 17-24. On the evening before the Congress proper, an exhibition of microbiology, parasitology and hygiene was opened at the Ministry of Education and Public Health by the Minister, Dr. Pedro Calmon. In the same room there was the Palais de la Découverte exhibition on the "Life and Works of Pasteur" : the French Ambassador was present and an address was given by Prof. René Farbe.

The first business on the morning of August 17 was the registration of members, and there followed a collective reception by the Minister.

In the afternoon the members were received at Catate Palace by His Excellency the President of the Republic, General Enrico Gasper Dutra, and then the Congress was formally opened at the Municipal Theatre, the President and many of his ministers being among those on the platform. Among others, the President of the Congress, Dr. Olympio da Fonseca, made a speech. After the opening session, members were taken to the Hotel Quintandinha and Petropolis, about forty miles away. The former served as headquarters for the Congress. It was most convenient for the majority to be housed and have their meetings in the same building. As it is 2,600 feet above sea-level the temperature was much more conducive to work than at Rio.

The programme was divided into eleven seetions: 1, Microbiology ; $2(a)$ Medical, and (b) Veterinary Bacteriology; 3, Virus and Virus Diseases; 4, Rickettsiæ and Rickettsial Diseases; 5, Mycology; 6, Protozoology; 7, Plant Pathogenic Micro-organisms ; $8(a)$ Water, Sewage, and $(b)$ Soil Microbiology ; 9, Industrial Microbiology; 10, Immunology and Allergy ; and 11, Classification and Nomenclature of Micro-organisms. The sessions were held from 9 a.m. until 1 p.m. on Friday, Saturday, Monday and
Wednesday, the afternoons being devoted to meetings of committees and sub-committees on various subjects. At 5 p.m. and 9 p.m. there were special lectures, followed by entertainment of divers kinds.

The Congress was a great success in every way. A volume of abstracts of papers was available on the first day and daily bulletins were issued giving changes in the programmes of different sections. Arrangements for illustrating the papers were excellent.

Many problems of immediate scientific interest were discussed in the different sections, as would be assumed from the grouping of the papers. Some of the programmes were very full, particularly those of microbiology and mycology. The first dealt mainly with matters common to all sections. The success of the second was remarkable in every way. All aspects of medical mycology received notice and most groups of fungi were touched upon, Coccidioides and Paracoccidioides having most attention. The seriousness of deep-seated granulomas in South America and the frequency of other fungal diseases of man and animals have given mycology a prominent place in medical studies there. Many of the papers presented showed a pleasing acquaintance with the requisites of classification and correct identification. Medical mycology, a subject full of difficulties, has had these magnified by descriptions and drawings of fungi which could have had no existence-a fact which has deterred investigations, possibly more particularly in Great Britain, where though fungus diseases are of little practical importance they are certainly not so rare as is commonly assumed. There is no doubt that their importance in South America is realized and that excellent work is being carried out there. The deliberations of the section should have wide-reaching effects on medical mycology. Other aspects of mycology were considered in other sections, including that of plant pathology. It has been suggested that this last section should in future specialize in bacterial, protozoological and virus diseases.

On Sunday, after solemn mass at Petropolis Cathedral, some members went to the Jockey Club at Rio, while others visited the National Park at Teresopolis. This is one of the five Brazilian National Parks and is conveniently situated near Rio in the Organ Range. One of the objects of the Park is to demonstrate how the retention of the tree cover of mountain slopes prevents soil erosion : there is alarm everywhere about destructive exploitation, but apparently no unified action. The entrance to the Park has been made into a garden, but there is a tendency to make too many roads ; also, in view of the great natural beauty, marigolds, pinks and other common European garden plants seem out of place.

Tuesday morning was spent visiting the famous Oswaldo Cruz Institute, which is celebrating its fiftieth anniversary, and of which Dr. Olympio da Fonseca, the president of the Congress, is the director. The scope of the investigations there being carried out is refreshingly wide and the morning proved all too short for the visit. After lunch at the Institute, Prof. Clementino Fraga gave a lecture at the Brazilian Academy of Letters on "Oswaldo Cruz : an Interpretation of Personality". There followed a reception by the Mayor of Rio at Guanabara Palace, and a performance which included an open-air ballet.

The main part of the final day was the closing session, at which the various recommendations of 